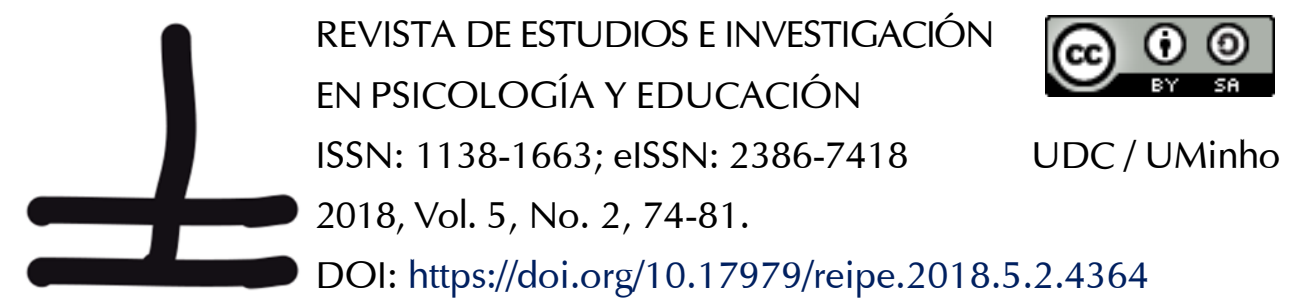

\title{
Parental Alienation Syndrome: A critique
}

\author{
Síndrome de alienación parental: una crítica
}

\author{
Brendan Willis (iD), William O’Donohue (iD) \\ University of Nevada, Reno
}

\begin{abstract}
Parental alienation syndrome (PAS), as defined by its creator Dr. Richard Gardner (2001), is a poorly defined, poorly researched, and controversial pseudoscientific construct arising primarily in the context of child custody disputes. The syndrome allegedly manifests as a non-rational and unjustified campaign of denigration against one parent during custody proceedings. It is purported to result from the combination of a parent's "brainwashing" and indoctrination regarding the vilification of the target parent. Unfortunately, there is little evidence to support that parental alienation represents a scientifically valid syndrome. There is no commonly recognized or empirically supported pathogenies, course, familiar pattern, or treatment selection indicated for the proposed symptoms of PAS. Additionally, it has been consistently excluded from both DSM-V and ICD10 , representing a near global rejection by the scientific community. When used in the legal context, PAS is exceptionally dangerous as it can conceal actual cases of abuse and cause children to be remanded into the custody of an abusive parent. Furthermore, it can be used as leverage to separate children from the caregiver that they are best suited to be with solely on the accusation of the non-preferred parent that they have been "alienated." In the interest of improving the scientific quality of custody evaluations and the safety of children, pseudoscientific theories such as parental alienation syndrome should be eliminated from the custody decision making process.
\end{abstract}

Keywords: Parental Alienation Syndrome; Child-Parent relationships; evidence-based Psychology; Legal Psychology; Forensic Psychology

\section{Resumen}

El Síndrome de Alienación Parental (SAP), tal como lo define su creador, el Dr. Richard Gardner (2001), es un constructo pseudocientífico mal definido, pobremente investigado y controvertido, que surge principalmente en el contexto de las disputas por la custodia de los hijos. El síndrome se manifiesta supuestamente como una campaña irracional e injustificada de denigración contra uno de los padres durante los procedimientos de custodia. Se supone que es el resultado de la combinación del "lavado de cerebro" de un/a progenitor/a y el adoctrinamiento con respecto a la difamación del padre/madre objetivo. Desafortunadamente, hay poca evidencia para apoyar que la alienación parental represente un síndrome científicamente válido. No hay patogenias, desarrollo de la patología, patrones familiares o selección de tratamientos a aplicar, que sean comúnmente reconocidos o con apoyo empírico, que sean indicados para actuar ante los síntomas propuestos del SAP. Además, se ha excluido reiteradamente tanto del DSM-V como de la CIE-10, lo que significa un

Brendan Willis (Dorcid.org/0000-0002-3714-728X, Clinical Psychology Doctoral Program, University of Nevada, Reno, 313 Mack Social Science Building, Reno, NV, 89557, USA.

William O’Donohue ${ }^{1}$ orcid.org/0000-0001-6679-6310, Professor, Director of Victims of Crime Treatment Center, Director of Psychological Services, Psychology Department, University of Nevada, Reno, Edmund J. Cain Hall, Reno, NV, USA.

Author of correspondence: Brendan Willis - brendanwillis@nevada.unr.edu 
rechazo casi total por parte de la comunidad científica. Cuando se emplea en el contexto legal, el SAP es excepcionalmente peligroso, ya que puede ocultar casos reales de abuso y hacer que los niños queden bajo la custodia de un padre/madre que esté abusando de ellos. Además, se puede utilizar como justificación para separar a los niños del cuidador/a con el que mejor se encuentran, ante la acusación del no preferido/a por ellos de que han sido "alienados". Con el fin de mejorar la calidad científica de las evaluaciones psicológicas realizadas en los procesos de custodia y para actuar asegurando la seguridad de los niños, las teorías pseudocientíficas como el Síndrome de Alienación Parental deben eliminarse del proceso de toma de decisiones sobre la custodia de menores.

Palabras clave: Síndrome de Alienación Parental; relaciones padres-hijos; Psicología basada en la evidencia; Psicología Legal; Psicología Forense

Parental alienation syndrome, as defined by Dr. Richard Gardner (2001), is a poorly defined, poorly researched and controversial, construct arising primarily in the context of child custody disputes. It is allegedly manifested by a so called "child's campaign of denigration against a parent" (Gardner, 2001, p 10). This supposed campaign of denigration has no rational justification, and instead is purported to result from the combination of a parent's "brainwashing" and indoctrination regarding the vilification of the target parent. This syndrome was, in part, intended to explain a child's hostility or negative reactions to a parent during divorce proceedings in the absence of evidence of abuse. Often the parent responsibly for this "brainwashing" would be a mother with a pathological need to alienate the child from their father during the divorce proceedings (Meier, 2009).

The goal of this paper is to briefly review the literature surrounding the parental alienation syndrome debate and more specifically examine whether or not it qualifies as a scientifically supported syndrome. This paper will also examine the use of parental alienation syndrome in the legal context. Other authors have provided more extended critiques of PAS. For example, O'Donohue, Benuto and Bennett (2016) have suggested that PAS suffers from the following problems: 1) it is vague in important details; 2) PAS entails measurement operations that have not been developed; 3) PAS has not undergone scientific testing sine it has been proposed; 4) It is not clear what the boundary conditions of PAS are; 5) It has not received a positive consensus in the field; 6) its prevalence is unknown; 7) its error rate is unknown; 8) PAS at times suggests the obvious and should receive no corroboration because it makes no risky prediction; 9) it fails to consider alternative more plausible explanations; 10) differential diagnoses are essential but lacking; 11) it is used in an ad hoc manner; 12) It was published in a peer reviewed journal but so have many critiques; 13) It has not been accepted by any official professional organization; 14) It fails to consider what is normative in divorce; 15) It fails to consider how positive events may mitigate; 16) it fails to consider that a child may be the cause of the alleged alienation; 17) it fails to consider that negative states the child may be experiencing may be caused by other events; 19) it is both developmentally and culturally insensitive; 20) It fails to consider that other people may be involved in the child's negative views; and 21) it may cause harm. Taken together, these points cast serious doubt on whether or not parental alienation syndrome can be considered to be scientifically based.

\section{The scientific status of Parental Alienation Syndrome}

In beginning to evaluate the parental alienation syndrome, it is important to first answer the question of what constitutes a scientifically supported syndrome. According to the Merriam-Webster Medical Dictionary, a syndrome can be defined as a group of signs and symptoms that consistently occur together and characterize a particular abnormality or condition (Merriam WebsterMedical Dictionary, 2017). Syndromes can also be defined combinations of symptoms either commonly occurring together or resulting from a single root cause as to constitute a distinct clinical picture (Miller, 1992). Finally, Kelly and Johnston (2001) pointed out that among the requirements for a syndrome, there must be a commonly recognized or empirically supported pathogenies, course, familiar pattern, or treatment selection indicated for the set of identified symptoms.

\section{What does a scientifically supported syndrome look like?}

The Diagnostic and Statistical Manual of Mental Disorders, $5^{\text {th }}$ Edition's construct of Posttraumatic Stress Disorder (PTSD) can be seen as a disorder or syndrome that meets the criteria used by Kelly and Johnston (2001) as well as the previously stated definitions (American Psychiatric Association, 2013). PTSD has widespread empirically support as a diagnosis based on a multiple independent research studies (Monson, Resick, \& Rizvi, 2014). While there is some debate regarding the exact mechanisms that are involved in the development of PTSD, comprehensive theories have emerged to supply explanations of the pathogenesis of the disorder (e.g., development of a fear network, Foa, Steketee, \& Rothbaum, 1989). Furthermore, from many randomly controlled trials there are empirically supported treatments (i.e., prolonged exposure) for PTSD and an understanding 
of the course it will take, either in treatment or when left untreated (Foa \& Rothbaum, 2007). The definition of PTSD, as described in the DSM-V, meets the criteria of the previous syndrome definitions. Specifically, there is a cluster of symptoms (e.g., re-experiencing, changes in cognition, hypervigilance) that occur after experiencing a specific casual factor (a Category A traumatic event), and these have occurred reliably together to the point where they constitute a distinct clinical picture (American Psychiatric Association, 2013).

\section{Does Parental Alienation Syndrome meet the criteria of a scientifically supported syndrome?}

The question remains does parental alienation syndrome meet the criteria of a scientifically valid syndrome as PTSD does? According to the majority of the scientific literature, the answer is a resounding no. There is no scientific research that reveals an empirically supported treatment or empirically verified pathogenesis for parental alienation syndrome (Kelly \& Johnston, 2001). For decades, the treatment Gardner recommended for parental alienation syndrome lacked empirical support or testing and had been linked to extremely intragenic effects on children and parents involved. Specifically, Gardner's therapy involved a complete denial of contact to the "alienating" parent in order to de-program the child and change their belief that they had been abused (Bruch, 2001; Gardner, 1992a). In some cases, children who have been forced into these procedures have either made threats of suicide or have actually killed themselves in reaction to court orders to undergo this de-programming treatment (Meir, 2009). Parent-child family relations have been disrupted and seriously harmed. This demonstrates not only the lack of a commonly accepted or empirically supported treatment for parental alienation syndrome, but also the fact that the sole therapy proposed for its treatment has documented evidence against its efficacy and its potential for severe intragenic effects.

Further damaging parental alienation syndrome's status as a scientifically supported syndrome has been details uncovered about its proposed course. Gardner predicted that parental alienation syndrome, if left untreated, would severely undermine the child's emotional and psychological development, however no evidence has been found to support this claim (Johnston \& Kelly, 2004). On the contrary, Wallerstein et al. (2000) reported that children's hostility towards a specific parent during a divorce was often temporary and would typically resolve itself of its own accord within one to two years. The importance of this empirical finding cannot be overstated. Evidence from Wallerstein et al. (2000) and other similar studies have undermined much of the reason for parental alienation syndrome's existence, namely that one parent is able to "brainwash" a child into hating the other parent and that brainwashing will result in long term negative consequences. Instead, empirical data suggest that even if children are somehow convinced to hate a particular parent (and this claim itself is dubious, as children tend to be resilient to attempts at "brainwashing" as outlined by Meier (2009)), this hate (even if unfounded) can resolve itself without long term consequences within a relatively short period of time without the need to intervene at all.

If the circumstances that produce parental alienation syndrome do not create a set of commonly agreed upon symptoms that have been investigated empirically, then it simply cannot be called a syndrome. Adding to this is the aforementioned facts that there is not an agreed upon pathogenesis of the disorder. Gardner asserts a model of how the syndrome allegedly develops, but there are no empirical studies to support this, despite the decades since the alleged syndrome was proposed (Meier, 2009). To the contrary, the lone empirical study of parental alienation syndrome did little to provide evidence to support the theory (Rueda, 2004). The study was designed to examine the extent to which different observers can correctly and consistently identify parental alienation syndrome. The study involved measuring the degree to which a small sample of therapists agreed on whether five case scenarios met Gardner's criteria for parental alienation syndrome. The study suffered from a number of limitations, most significantly that many of the clinicians surveyed refused to complete the questionnaire, some specifically citing their nonbelief in parental alienation syndrome. Additionally, the study failed to examine or answer the key question regarding whether or not parental alienation syndrome is an actual disorder caused by a malevolent parent "brainwashing" a child against the other parent. Rather, the study simply assumed this to be the case (Meier, 2009). This study did not empirically establish links between the causal factors in Gardner's model to his predicted outcomes. Without this support, the syndrome status of parental alienation is further weakened.

Parental alienation syndrome fails spectacularly at another key criteria of the definition of a syndrome, namely that it be based factors that are commonly recognized. Quite the opposite appears to be true based on the volume of literature that has come out against parental alienation syndrome (Gould, 2006; Myers et al., 2002). One of the clearest examples of parental alienation syndrome's failure to garner support in scientific community is its continued rejection by the American Psychiatric Association from inclusion in the Diagnostic and Statistical Manual of Mental Disorders. Both the $4^{\text {th }}$ and $5^{\text {th }}$ versions of the manual did not include parental alienation syndrome, despite heavy advocacy by Gardner and his colleagues (Meier, 2009). The limitations of the DSM are well known, but the fact that the committees behind the DSM found parental alienation syndrome lacking sufficient empirical basis speaks volumes about its nonscientific status. The syndrome has also failed to garner support in the larger international community, as evidenced by its absence in the World Health Organization's International Classification 
of Diseases $10^{\text {th }}$ Revision (World Health Organization, 2016). Both of these facts represent a failure on the part of parental alienation syndrome to achieve anything resembling an agreed upon cluster of symptoms that can be defined as a distinct clinical picture. Furthermore, the American Psychological Association itself has soundly rejected parental alienation syndrome, stating that there is no data to support a phenomenon of mothers interfering with their children's attachment to their fathers. They also cite the danger that parental alienation syndrome can be used to discount children's fears and obscure the truth of allegations of abuse during custody proceedings (American Psychological Association, 1996).

Gardner (2004a) attempted to respond to the critique that parental alienation syndrome does not represent a scientifically valid syndrome by using Campbell (1989)'s definition and by stating that parental alienation syndrome meets each of Campbell's requirements. Specifically, Campbell (1989) stated that there are 3 levels of progression towards the recognition of a syndrome. The first is isolating signs or symptoms without apparent linkages to one another. The second is forming a clinical picture by grouping specific signs and symptoms together into a distinctive syndrome. The final level is the identification of a particular casual pathway or pathogenesis that accounts for the constellation of symptoms. Gardner (2004a) states that parental alienation syndrome has succeeded in isolating signs and symptoms, and maintains that more than 147 articles have been published regarding the existence of the syndrome itself, satisfying level 2. He further asserts that the third level has also been satisfied, in that the programming parent is responsible for the development of the disorder. However, closer inspection reveals that parental alienation syndrome fails to meet even the criteria set forth by Gardner himself. While it is indeed true that symptoms have been identified, no empirical research has been able to verify Gardner's proposed linkages between the symptoms of parental alienation syndrome. As stated before, both the DSM and $I C D-10$ lack any mention of parental alienation syndrome, indicating the symptoms he has observed do not constitute a distinctive syndrome. Taken together, these points damage his argument that parental alienation syndrome satisfies the second of Campbell's criteria. Whether PAS meets the requirements of the third criteria (identification of casual pathways or pathogenesis which accounts for the presenting symptoms) is also dubious. While many articles have been published on the subject of parental alienation syndrome, none of them have been independent, objective, or public replications of Gardner's own assertions (Emery, 2005). Furthermore, as Emery (2005) points out, the majority of evidence that has been offered in support of parental alienation syndrome is in the form of case studies, which are excellent for generating hypotheses, but they are of no value in hypothesis testing. Only one statistical analysis was conducted on the subject of parental alienation syndrome, and it was conducted by Gardner himself (Emery, 2005), however, there have been no replications of this study. The lack of independent statistical studies testing or replicating the mechanisms and propositions of Gardner's model and the overall dearth of empirical support for the syndrome itself indicates that parental alienation syndrome fails Campbell's third criteria, that the observed symptoms be linked to a casual factor.

Furthermore, there is mounting evidence that parental alienation syndrome's theoretical claims are not simply unsupported, but in actuality false. Parental alienation syndrome presumes that vengeful mothers will pathologically program their children to hate their fathers and invent claims of abuse, but research suggests that noncustodial fathers are more likely to fabricate child maltreatment claims (Meier, 2009). Research by Trocme and Bala (2005) found that intentionally false reports of abuse were given by noncustodial parents (often fathers) $43 \%$ of the time. Only $14 \%$ of intentionally false claims were made by a custodial parent, typically mothers. Finally, O'Donohue, Benuto \& Bennett (2016) states that there are several fundamental questions remain unanswered and sometimes are unchallenged in family court:

1. In what percentage of divorce cases are the behaviors described by PAS actually exhibited?

2. By what causal processes do these develop?

3. What effects do these behaviors actually have on the children?

4. Are there moderating influences regarding these effects?

5. How can one validly measure all this and show causality?

6. If these effects are found what can be done to intervene, both in custody and/or visitation arrangements or clinically to reverse these effects?

However, these authors also note that to date, none of these questions have been answered in over 25 years since PAS was first promulgated (O'Donohue, Benuto \& Bennett, 2016).

Overall, despite Gardner (2004a)'s claims that parental alienation syndrome meets the requirements of a criteria as outlined by Campbell (1989), it is clear that the disorder does not meet even those requirements. Of Campbell's three levels needed to recognize a syndrome, the first is the only one that parental alienation syndrome plausibly can meet. A series of symptoms have been identified (anger, hatred toward a parent during divorce proceedings, a refusal to see or meet with that parent, etc.). However, there is little indication that these symptoms cohere in the way that Gardner predicted or that his attributed causal mechanism (parental brainwashing) actually causes the constellation of symptoms he described.

Several final notes are pertinent to assessing the scientific validity of parental alienation syndrome. First is the danger caused by the structure of the supposed syndrome itself. Parental alienation syndrome is a 
tautological argument, (i.e. one that is true by definition) and thus is unfalsifiable (Johnston \& Kelly, 2001). No matter what research is conducted on the theory, in its present form the theory cannot be disproven. Meier (2009) points out that parental alienation syndrome is a lawyer's dream because all evidence an accused mother can bring to bear against it can be refuted and reframed as confirming the syndrome. If a child states that he or she has been abused, then this is taken to be evidence of the syndrome. If a clinician who has examined the child states that there is no evidence that the child has been abused, then the clinician can be accused of being duped by the vengeful mother's campaign against the father. As pointed out by O'Donohue and Willis (in press), scientific theories must be falsifiable. They must be testable and there must be a chance that the theory can be proven wrong. A lack of falsifiability is one of the hallmarks of pseudoscience. Fake science is defined by circular arguments where all evidence against the theory can be refuted or turned to support the theory itself, which is exactly how parental alienation syndrome is structured. Indeed, Sir Karl Popper (1963) describes a particular encounter which bears a distinct similarity to the current issue:

As for Adler, I was much impressed by a personal experience. Once in 1919, I reported to him a case which to me did not seem particularly Adlerian, but which he found no difficulty in analyzing in terms of his theory of inferiority feelings, although he had not even seen the child. Slightly shocked, I asked him how he could be so sure. 'Because of my thousand fold experiences,' he replied; whereupon I could not help say: 'And with this new case, I supposed, your experience has become thousand and one fold.' (p. 35)

As shown here, Alder could conceptualize any case as Alderian based on his "thousand fold experience," regardless of whether or not it actually fit in with Alderian conceptualizations. Similarly, parental alienation syndrome can turn any accusation of abuse against a father into an alienation case where the mother is fabricating the entire story.

On the subject of pseudoscientific claims, many of the other claims that form the basis of parental alienation syndrome are based more on pseudoscientific beliefs than empirical research. For example, he claimed that the reason that women lie about the abuse of their children during custody litigation is that "hell hath no fury like a woman scorned" (Gardner, 1992b, pp. 218-219), a distinctly nonscientific reason. Meier (2009) states that Gardner's additional reason for explaining why the majority of alienating parents were mothers was that mothers were gratified vicariously by imagining their child having sex with their estranged husband. These wild claims have no empirical support and serve only to further harmful stereotypes and obscure the truth during legal proceedings. Furthermore, Gardner (2004b) also attempted to draw connections between parental alienation syndrome and another pseudoscientific syndrome, false memory syndrome (Dallam, 2002). False memory syndrome is described as a widespread phenomenon involving misguided therapists who use therapeutic strategies that cause the invention of memories of sexual abuse where there were none to begin with. Specifically, Gardner (2004b) attempted to describe the similarities and differences between both syndromes. He purports that parental alienation syndrome is similar to false memory syndrome in that they both share a common campaign of acrimony against a parent. Both syndromes are supposed to be defined by similar factors, such as the child (or young woman in the case of false memory syndrome) having an absence of guilt over cruel behaviors directed at the alienated parent. Furthermore, both apparently involved the persistent belief that one has been sexually abused when one has not been, the belief that the perpetrator was a close family member, and hysteria. Unfortunately, no empirical support was provided for these claims. False memory syndrome itself suffers from a variety of shortcomings and has been classified as a pseudoscientific theory that based solely on the reports of parents who claim to be falsely accused of incestuous abuse (Dallam, 2002). Adding such a pseudoscientific theory in an attempt to shore up the already dubious parental alienation syndrome does not increase its validity or scientific basis.

A variety of other critiques abound for parental alienation syndrome, too many to be described fully here. However, some of the most salient critiques are as follows. Even if parental alienation syndrome could be classified as a non-diagnostic syndrome, it does not provide any information on the cause, prognosis, or treatment of these behaviors (Johnston \& Kelly, 2001). The syndrome as defined offers a clinician little guide in conceptualizing the patient beyond existing evidence-based methods steeped in the cognitive behavioral tradition. It also fails to indicate an ideal course of treatment or explain how existing methods may be adapted for the treatment of the syndrome. In summation, this indicates that parental alienation syndrome entirely lacks clinical utility and would not be recommended for use as a diagnosis (Persons, 2008). Furthermore, there is no instrument designed to measures parent alienation syndrome (Emery, Otto, \& O'Donohue, 2005). There is no objective measure, no structured interview, and no reliable or valid scale that exists to detect the presence of this syndrome. It can only be detected through non-structured clinical interviews. This further complicates parental alienation syndrome's scientific status, as there exists no way of measuring it in an objective way for research or clinical purposes. This frustrates attempts at subjecting it to quantitative analysis and statistical hypothesis testing. Lastly, there exists a serious methodological flaw in Gardner's research. Often only one parent would be evaluated during his custody assessments (Emery, Otto, \& O’Donohue, 2005). By not interviewing 
both parents, it is next to impossible to gain a complete picture of both parent's behaviors in their familial context. Indeed, Gardner's fears that a naive psychotherapist could be manipulated by a vengeful mother would likely increase using his methods. Interviewing only one of the parents increases the likelihood of receiving a one-sided version of events without the ability to check the account by referring to the other parent's story.

The evidence is mounting that parental alienation syndrome should not be considered to be a scientifically supported syndrome or diagnosis. Overall, it has been soundly rejected by the scientific community at large. It is based on research that fails to meet acceptable standards of evidence or rigorous scientific methods. Finally, the definition of the syndrome itself place parental alienation squarely in the category of pseudoscience. Pseudoscience lacks authentic attempts at error elimination and ad hoc hypotheses are used to save pseudoscientific theories from refutation and to discount disconfirming evidence. Parental alienation syndrome is a tautological theory and therefore, because it cannot be falsified, it should be classified as a pseudoscientific theory.

\section{The use of Parental Alienation Syndrome in the legal context}

Despite the vast evidence to suggest that parental alienation syndrome does not meet the qualifications of a scientifically valid syndrome, it unfortunately still does appear in legal contexts. However, there has been an intensifying movement to prevent the use of parental alienation in courts throughout the United States. For example, The National Council of Juvenile and Family Court Judges asserted that parental alienation syndrome was scientifically invalid and inappropriately asks courts and judges to assume that a child's behavior toward the so called "alienated parent" has no grounding or basis in reality (Dalton, Drozd, \& Wong, 2006). By claiming that the allegations are false due to parental alienation syndrome, this forestalls further investigation into the nature of the allegations and can obscure actual cases of abuse and neglect. Supporting this statement, both the American Prosecutors' Research Institute and the National District Attorneys' Association have rejected parental alienation syndrome (Ragland \& Fields, 2003). Specifically, they indicated that the syndrome only attempts to explain behavior while not providing treatment or other recommendations. Further, they state that it is an untested theory that prosecutors and other child abuse professionals need to be aware of, as it only benefits adversaries involved in legal sparing.

Interestingly, legal opposition to parental alienation syndrome is not solely limited to the United States of America. The Public Defender of Rights, the Commissioner for Children, and the Coalition for Children in the nation of Slovakia released a stern declaration stating that parental alienation syndrome is not an official syndrome and is, in effect, a "discredited diagnosis" (Ministerstvo Spravodlivosti Sr, 2011, p.1). Instead of relying on untested and pseudoscientific theories, the Common Declaration states Slovakian courts should insist on a complete and thorough psychological assessment of the factors that can contribute to deciding which parent will receive custody during divorce proceedings. Furthermore, the Common Declaration indicates that to adhere to the discredited diagnosis of parental alienation syndrome is tantamount to violating the case law of the European Court of Human Rights, which states that the court and state have obligations to provide sufficient protection for victims of domestic violence or sexual abuse. The Slovakian authorities have clearly decided that parental alienation syndrome represents a danger to the wellbeing of children in the recommendation that it not be used during cases of child custody.

The preceding findings do not discount the rare event when a parent does attempt to use a child as a pawn against a former spouse during divorce proceedings. In dealing with those rare occasions, Meier (2009) has provided 6 recommendations for assessing alienation and avoiding the pitfalls of Gardner's problematic construct. These steps are as follows (italics added): 1) Assess the possibility of abuse first, 2) Require evaluators to have genuine expertise in both child abuse and domestic violence, 3) Once abuse is found, alienation claims by the accused abuser should not be considered, 4) A finding of alienation should not be based on unconfirmed abuse allegation or protective measures by the favored parent, 5) Alienation claims should be evaluated only under 2 conditions: if the child is actually unreasonably hostile to the other parent and resistant to visits and there is actual active alienating behavior by the aligned parent, and finally 6) A parent may only be accused of alienation where the parent consciously intends the alienation and specific behaviors can be identified. Meier (2009) hopes that recommendations such as these will assist courts and evaluators to more clearly see the complex situations involved in custody disputes and avoid the tragic situation of ignoring actual abuse in favor of following a pseudoscientific theory.

\section{Conclusion}

Sondgrass and Scheere (1989) described the courtroom as a crucible where irrelevancies are burned away to reveal truth. In that spirit, it is vital that we dispose of the irrelevancy of pseudoscientific theories such as parental alienation syndrome. Not only does this discredited speculation rely on untested theory and conjecture, it has the potential for significant damage. Parental alienation syndrome can conceal actual cases of abuse and cause children to be remanded into the custody of an abusive parent. Furthermore, it can be used as leverage to separate children from the caregiver that they are best suited to be 
with solely on the accusation of the non-preferred parent that they have been "alienated." In the interest of improving the scientific quality of custody evaluations and the safety of children, pseudoscientific theories such as parental alienation syndrome should be eliminated from the custody decision making process.

\section{References}

American Psychiatric Association. (2013). Diagnostic and Statistical Manual of Mental Disorders (5th ed.). Arlington, VA: American Psychiatric Association.

American Psychological Association. (1996). Report of the American Psychological Association Presidential Task Force on Violence and the Family. Washington, DC: American Psychological Association.

Bruch, C.S. (2001). Parental Alienation Syndrome and Parental Alienation: Getting It Wrong in Child Custody Cases. Family Law Quarterly, 35, 527-552. https://doi. org/10.2139/ssrn.298110

Campbell, R. J. (1989). Psychiatric dictionary (6th ed.). New York and Oxford: Oxford University Press.

Emery, R. E. (2005). Parental Alienation Syndrome: Proponents Bear the Burden of Proof, 43, Family Court Review, 8, 11-12. https://doi.org/10.1111/j.1744-1617. 2005.00002.x

Emery, R. E., Otto, R. K., \& O'Donohue, W. T. (2005). A critical assessment of child custody evaluations: Limited science and a flawed system. Psychological Science in the Public Interest, 6(1), 1-29. https:// doi.org/10.1111/j.1529-1006.2005.00020.x

Dallam, S. J. (2002). Crisis or creation? A systematic examination of false memory syndrome. Journal of Child Sexual Abuse, 9(3-4), 9-36. https://doi.org/ 10.1300/J070v09n03 02

Dalton, C., Drozd, L., \& Wong, F. (2006). Navigating Custody and Visitation Evaluations in Cases with Domestic Violence: A Judge's Guide (Rev. ed.). Reno, NV: National Council of Juvenile \& Family Court Judges.

Foa, E. B., Hembree, E. A., \& Rothbaum, B. O. (2007). Prolonged exposure therapy for PTSD: Emotional processing of traumatic events. New York City, New York: Oxford University Press.

Foa, E. B., Steketee, G., \& Rothbaum, B. O. (1989). Behavioral/cognitive conceptualizations of posttraumatic stress disorder. Behavior Therapy, 20, 155176. https://doi.org/10.1016/S0005-7894(89)80067-X

Gardner, R.A. (1992a). The Parental Alienation Syndrome: A Guide for Mental Health and Legal Professionals. Cresskill, NJ: Creative Therapeutics.

Gardner, R.A. (1992b). True and False Accusations of Child Sex Abuse. Cresskill, NJ: Creative Therapeutics.

Gardner, R. A. (2001). Parental alienation syndrome (PAS): Sixteen years later. In Academy Forum (Vol. 45, No. 1, pp. 10-12).
Gardner, R. A. (2004a). Commentary on Kelly and Johnston's "The alienated child: A reformulation of parental alienation syndrome". Family Court Review, 42(4), 611-621. https://doi.org/10.1177/1531244504268711

Gardner, R. A. (2004b). The relationship between the parental alienation syndrome (PAS) and the False Memory Syndrome (FMS). The American Journal of Family Therapy, 32(2), 79-99. https://doi.org/10.1080/ 01926180490424181

Gould, J.W. (2006). Conducting Scientifically Crafted Child Custody Evaluations (2nd ed.). Sarasota, FL: Professional Resource Press.

Johnston, J. R., \& Kelly, J. B. (2001). The alienated child: A reformulation of parental alienation syndrome. Family Court Review, 39(3), 249-266. https://doi.org/ 10.1111/j.174-1617.2001.tb00609.x

Johnston, J. R., \& Kelly, J. B. (2004). Commentary on Walker, Brantley, and Rigsbee's (2004) "A Critical Analysis of Parental Alienation Syndrome and Its Admissibility in the Family Court". Journal of Child Custody, 1(4), 77-89. https://doi.org/10.1300/J190v01 n04_05

Meier, J. S. (2009). Parental alienation syndrome and parental alienation: Research reviews. Retrieved from http://www.vawnet.org/Assoc_Files_VAWnet/AR_PA S.pdf

Merriam-Webster Medical Dictionary. (2017, December 1). Syndrome. Retrieved December 23, 2017, from Meriam-Webster Medical Dictionary: https://www. merriam-webster.com/dictionary/syndrome\#medical Dictionary

Miller, B. F. (1992). Encyclopedia and dictionary of medicine nursing and allied health (95th ed.). Philadelphia, PA: Saunders.

Ministerstvo Spravodlivosti Sr. (2011). The Declaration on so Called 'Parental Alienation Syndrome'. Retrieved December 9, 2017, from www.justice.gov.sk/Stranky/ aktualitadetail.aspx?announcementID $=2081$

Monson, C. M., Resick, P. A., \& Rizvi, S. L. (2014). Posttraumatic Stress Disorder. In D. H. Barlow (Ed.), Clinical handbook of psychological disorders (pp. 62114). New York City, New York: Guilford Press.

Myers, J., Berliner, L., Briere, J., Hendrix, C.T., Jenny, C., $\&$ Reid, T.A. (Eds.). (2002). The APSAC Handbook on Child Maltreatment (2nd ed.). Thousand Oaks, CA: Sage Publications.

O'Donohue, W., Benuto, L., \& Bennett, N. (2016). Examining the validity of the parent alienation syndrome. Journal of Child Custody, 13, 113-125. https://doi.org/10.1080/15379418.2016.1217758

O'Donohue, W. T., \& Willis, B. M. (In Press). Problematic images of science in undergraduate psychology textbooks: How well is science understood and depicted? Archives of Scientific Psychology.

Persons, J. B. (2008). The case formulation approach to cognitive-behavioral therapy. New York, NY: Guilford Press. 
Popper, K. R. (1963). Conjectures and refutations. London, UK: Routledge and Kegan Paul.

Ragland, E.R., \& Field, H. (2003). Parental Alienation Syndrome: What professionals need to know. Update Newsletter, 16(6). Alexandria, VA: National District Attorneys Association's American Prosecutors Research Institute. Retrieved December 24, 2017, from http://www.ndaa.org/ncpca_update_v16_no6.html

Rueda, C.A. (2004). An Inter-Rater Reliability Study of Parental Alienation Syndrome. The American Journal of Family Therapy, 32, 391-403. https://doi.org/10. 1080/01926180490499864

Snodgrass, Melinda M. (Writer), \& Scheerer, Robert. (Director). (1989). Measure of a Man [Television series episode]. In Roddenberry, Gene. (Executive Producer), Star Trek: The Next Generation. Los Angeles, CA: Columbia Broadcasting System.

Thoennes, N., \& Tjaden, P. (1990). The Extent, Nature, and Validity of Sexual Abuse Allegations in Custody/Visitation Disputes. Child Abuse and Neglect, 14, 151-163. https://doi.org/10.1016/0145-2134(90) 90026-P

Wallerstein, J.S., Lewis, J.M., \& Blakeslee, S. (2000). The Unexpected Legacy of Divorce: A 25 Year Landmark Study. New York: Hyperion Books.

World Health Organization. (2016). ICD-10 Version: 2016. Retrieved from WHO | ICD-10: http://apps.who.int/ classifications/icd10/browse/2016/en

Fecha de recepción: 28 de septiembre de 2018.

Fecha de revisión: 14 de octubre de 2018. Fecha de aceptación: 15 de octubre de 2018. Fecha de publicación: 1 de diciembre de 2018. 